\title{
Career Adaptability of Marine Cadets: A Descriptive Study
}

\author{
Wiwik Sulistiani \\ Doctoral Program in Psychology, Faculty of Psychology, Universitas Airlangga, \\ Faculty of Psychology Universitas Hang Tuah \\ wiecha0I@gmail.com \\ Dewi Retno Suminar \\ Faculty of Psychology, Universitas Airlangga \\ dewi.suminar@psikologi.unair.ac.id \\ Wiwin Hendriani \\ Faculty of Psychology, Universitas Airlangga \\ wiwin.hendriani@psikologi.unair.ac.id
}

\begin{abstract}
Issues pertaining to career often arise during higher education period. Common problems during such period of career development include choosing, deciding, and maintaining a career, including maintaining one's choice of career. The aim of this study is to describe the career adaptability of marine cadets and see differences in career adaptability based on gender. Participants are marine cadets from a private university in Surabaya, Indonesia. Data was collected using an Indonesian version of Career Adaptability scale (CAAS). Result provides description on cadets' career adaptability, as follows: $1.5 \%$ was categorized as "low", 35.4.2\% "moderate", and 63.1\% "high". Comparison of standard deviations shows that the career adaptability of marine cadets had low variation. It shows that all indicators of career adaptability among marine cadets played roles in shaping career adaptability and have balanced similarities. The second result shows there is no difference in career adaptability between male cadets and female cadets. These findings can be used as a reference for schools and educators related to career adaptability of cadets.
\end{abstract}

Keywords: career adaptability, category, marine cadets

Received 17 May 2019/Accepted 2 September 2019 @JEHCP All rights reserved

\section{Introduction}

Issues pertaining to career often come up when an individual enters higher education, in which they would be preparing themselves for future career. During early years of higher education, one must make a decision about their future job and education. It is very important as it relates to the 
process of career decision making and adaptability skill (Buyukgoze-kavas, 20I4). Some issues during the period of career development are choosing and maintaining the chosen career pathway, including one's choice of education. Individual ability to maintain career of their choice even during moments of pressure is called career adaptability (Indianti, 2015). Various research findings indicate that career adaptation is relevant to students' situation when preparing career in working world (Guan et al., 20I5; Indianti, 20I5; Merino-Tejedor, Hontangas, \& Boada-grau, 2016; Tian \& Fan, 20I4).

Career adaptability issues also occur among marine cadets. Merchant marine education differs from other programs in universities. Students are taught knowledge and skills to be a reliable and readyfor-work cadet in merchant marine sector. As a vocational program, merchant marine education has some particular rules during the program. Norms of conduct for cadets of merchant marine education in Indonesia significantly contain mental and moral development, rights and obligations, cadet organization, regular daily orders, manner, prohibition, and norm violation. Behaviors of a cadet are reflected in those norms of conduct (Winarno, 2016). One of merchant marine education is in Surabaya.

One cadet reported during an interview that it takes physical and mental readiness to be in a merchant marine education program. Education in such program demands a lot of high quality academic and non-academic requirements. Many activities, both in campus and in dormitories, are not only about the learning materials. Cadets are expected to strictly follow regulations. Although having a great career as a sailor is the common reason to take merchant marine education, joining the program might actually feel difficult. During transition period, one is required to change themselves. Every individual has the quality to be able to change in accordance with new situations, or what is often termed "adaptability" (Savickas, 2007). Adaptation process to change various conditions encourages an individual to learn and develop even further (Savickas; in Brown, 2002). In building a career, an individual does not only direct themselves towards a job, but also develops work attitudes so that they can be more skilled. A frequent difficulty is that an individual cannot maintain their choice of education or career when facing some problems during the process (Paton and Mahon 2006). The common term used to discuss such problem is career adaptability. It is coined for the first time by Super who unfortunately never explicated it in sufficient depth. The 
concept of career adaptability was then developed by (Savickas, 2007) into a construct which can predict career development that indicates transitional period. Career adaptability is subsequently known as the Career Construction Theory (CCT). Career adaptability is one's readiness to face any possible challenge or difficulty during a career transition, preparing them to succeed in career (Savickas, 2005).

Being in an environment, such as the merchant marine education, which has regulations and norms differing from those of previous experience, requires high level of career adaptation. Academic and non-academic demands, regulation, and mental coaching during the program will require career adaptation, by constantly trying to maintain one's choice of education in order to achieve the favored career. The question of this research is "how is the career adaptability of marine cadets in Surabaya?"

In terms of career, men have more career adaptability and feel job satisfaction than women (Han \& Rojewski, 2015). But some research shows a difference. Hirchi (2009) research results in Switzerland, showed no gender differences in career adaptability. Rosulin and Paramita's (2016) research on vocational students in Surabaya, shows that there are differences in career adaptability between male and female students. Male students have higher career adaptability compared to female students. Based on this, the researcher also wants to look at "the differences in career adaptability between male cadets and female cadets"

\section{Method}

\section{Participants}

This research used a quantitative approach with single variable, namely career adaptability. Research participants were cadets of merchant marine education in Surabaya. There were 206 cadets involved. Details on participants' demographics are presented in Table I. 


\section{Measures}

This research employed an Internationally standardized instrument to measure career adaptability, which is Career Adapt-Abilities Scale (CAAS) (Porfeli \& Savickas, 2012). CAAS has been tested internationally in 13 countries and has pronounced reliabilities across different cultural contexts. This research used the Indonesian version of CAAS (Sulistiani, Suminar, \& Hendriani, 2018), which was constructed based on the CAAS International Form 2.0 (Savickas \& Porfeli, 20I2), consisting of 24 items and providing scores to describe the career adaptability of an individual. All 24 items are distributed evenly into four subscales, as follows: (I) Career concern, i.e. focus on the future; (2) Career control, i.e. ability to control own self in order to achieve future career; (3) Career curiosity, i.e. curiosity to seek opportunities for future career; (4) Career confidence, i.e. having confidence in realizing future career. The scale uses Likert-scaling, ranging from I (weak) to 5 (strong). In addition to the CAAS, a demographic questionnaire was also included. The reliability coefficient for the CAAS Indonesian Form was $\alpha=.94$. Meanwhile, reliability coefficients for each subscale are as follows: career concern $(\alpha=.87)$, career control $(\alpha=.84)$, career curiosity $(\alpha=$ $.85)$, and career confidence $(\alpha=.87)$.

\section{Statistical Analysis}

This research used descriptive statistical analysis (i.e. mean, frequency, percentage, and standard deviation). In order to determine categories for career adaptability of marine cadets, researchers used comparison between hypothetical and empirical mean. Hypothetical mean is the mid-point in a measuring scale, while empirical mean is a mean score obtained from a research sample (Sufren \& Natanael, 2014). Categorization using hypothetical mean measures the actual condition of research participants and can result in proportion that does not follow normal curve (Widhiarso, 20l0). Frequency is used to described how many cadets are within category of high, moderate, and low. Percentages are used to rank each indicator of career adaptability, by comparing total item score and total item in each indicator. In addition, this study also looked at differences in career adaptability between male and female cadets, first-year cadets and second-year cadets. The analysis used to see this difference is to use the $t$ test. 
Table I

Participants' Demographics

\begin{tabular}{llc}
\hline Gender & Male & $88.35 \%$ \\
& Female & $11.65 \%$ \\
\hline Year & I & $58.25 \%$ \\
Origin & Java & $41.75 \%$ \\
& Madura & $73.3 \%$ \\
Reason to join the program & Outside Java and Madura & $11.65 \%$ \\
& Own self & $15.05 \%$ \\
& Parents & $27.18 \%$ \\
& Friend & $55.83 \%$ \\
& Own self and parents & $2.91 \%$ \\
& Own self and friend & $13.11 \%$ \\
& & $0.97 \%$ \\
\hline
\end{tabular}

\section{Result}

\section{Score Categories}

Based on categorization, participants of this research tended to fall into the moderate and high category. As much as $1.5 \%$ of participants was classified into "low" category, $35.4 \%$ into the "moderate", and the other 63.1\% was in "high" category. In details, this result is shown in Table 2 and Figure I.

Table 2

Score category

\begin{tabular}{|c|c|c|c|c|c|}
\hline & & Frequency & Percent & $\begin{array}{l}\text { Valid } \\
\text { Percent }\end{array}$ & $\begin{array}{l}\text { Cumulative } \\
\text { Percent }\end{array}$ \\
\hline \multirow[t]{4}{*}{ Valid } & Low & 3 & 1.5 & 1.5 & I.5 \\
\hline & Moderate & 73 & 35.4 & 35.4 & 36.9 \\
\hline & High & 130 & 63.1 & 63.1 & 100 \\
\hline & Total & 206 & 100 & 100 & \\
\hline
\end{tabular}




\section{Journal of Educational, Health and Community Psychology Vol 8, No 3, 2019 E-ISSN 2460-8467}

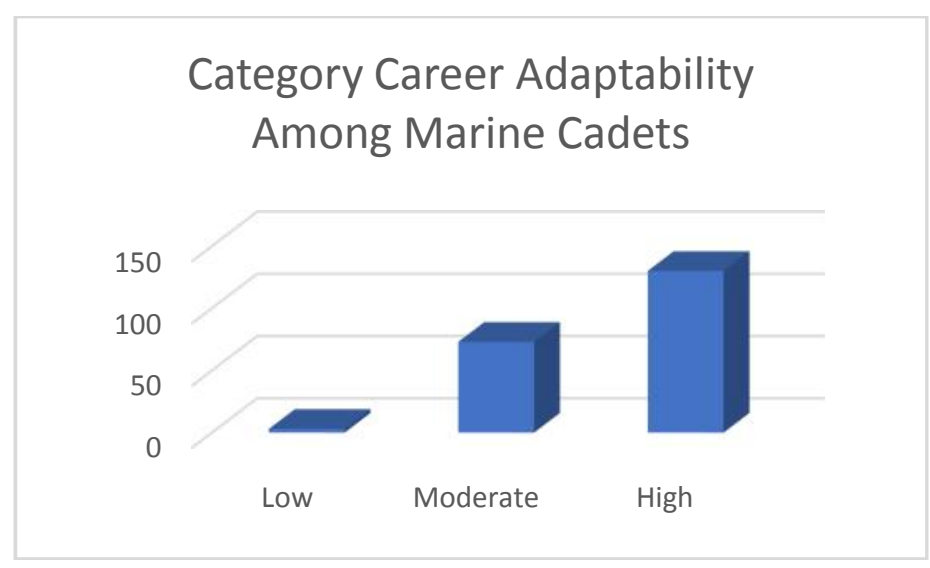

Figure I. Frequency of career adaptability categories among marine cadets

Based on Figure I, it seems that the majority of cadets merchant marine education in Surabaya, as classified into "high" category, although some were classified into moderate and low. It implies that not all cadets had high level of career adaptability.

Comparison between hypothetical and empirical mean

The obtained score of hypothetical mean $(\mu)$ of career adaptability were 72 , calculated using the following formula:

$$
\mu=\frac{1}{2}\left(\mathrm{i}_{\max }+\mathrm{i}_{\min }\right) \Sigma \mathrm{k}
$$

The hypothetical standard deviation $(\sigma)$ was 16 , calculated using the following formula: $\sigma=\frac{1}{6}\left(X_{\max }-X_{\min }\right)$

Meanwhile, the empirical mean $(\chi)$ was 93.39, as presented in Table 3.

Table 3

Descriptive Statistics

\begin{tabular}{llllll}
\hline & N & Minimum & Maximum & Mean & Std. Deviation \\
\hline Total & 206 & 53.00 & 120.00 & 93.39 & 15.42 \\
Valid N & 206 & & & & \\
\hline
\end{tabular}


Comparison between the two mean values shows that the empirical mean $(\chi=93,39)$ was higher than the theoretical mean $(\mu=72)$. This indicates that career adaptability of the marine cadets was high.

Comparison between standard deviation values.

Comparison between both theoretical and empirical values shows that empirical deviation value (s $=15,42)$ was lower than that of the hypothetical one $(\sigma=16)$. It implies that career adaptability of the cadets had low variation. To put it simply, the participants shared similar level of career adaptability.

To establish ranking among the indicators of career adaptability, percentage of ratio between total score item and total item in each indicator. According to Table 4, career adaptability of cadets of merchant marine education in Surabaya tended to be dominated by concern for career $(26.49 \%)$, followed by career control (25.80\%), career confidence (24.38\%), and lastly career curiosity (23.33\%). Nonetheless, in general, all indicators played balanced role in determining career adaptability.

\begin{tabular}{lcc}
$\begin{array}{l}\text { Table } 4 \\
\text { Indicator Rank }\end{array}$ & & \\
\hline Career Adaptability Dimension & Percent & Rank \\
\hline Concern & 26.49 & I \\
Control & 25.80 & II \\
Curiosity & 23.33 & IV \\
Confidence & 24.38 & III \\
\hline
\end{tabular}

The ranking of indicators is also better depicted in Figure 2. 


\section{Indicator Rank}

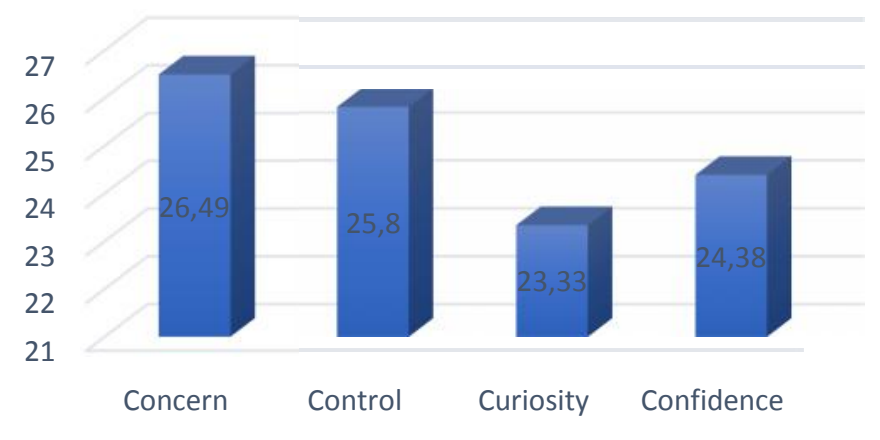

Figure 2. Indicator Rank

Different test results between male cadets and female cadets, first-year cadets and second-year cadets are explained in table 5.

\section{Table 5}

$T$ test analysis result

\begin{tabular}{|c|c|c|c|c|c|c|c|c|c|c|}
\hline & & \multicolumn{2}{|c|}{$\begin{array}{l}\text { Levene's Test for } \\
\text { Equality of } \\
\text { Variances }\end{array}$} & \multicolumn{7}{|c|}{ t-test for Equality of Means } \\
\hline & & \multirow[b]{2}{*}{$\mathrm{F}$} & \multirow[b]{2}{*}{ Sig } & \multirow[b]{2}{*}{$\mathrm{t}$} & \multirow[b]{2}{*}{$\mathrm{df}$} & \multirow{2}{*}{$\begin{array}{l}\text { Sig. (2- } \\
\text { tailed) }\end{array}$} & \multirow{2}{*}{$\begin{array}{c}\text { Mean } \\
\text { Difference }\end{array}$} & \multirow{2}{*}{$\begin{array}{l}\text { Std. Error } \\
\text { Difference }\end{array}$} & \multicolumn{2}{|c|}{$\begin{array}{l}\text { 95\% Confidence Interval of } \\
\text { the Difference }\end{array}$} \\
\hline & & & & & & & & & Lower & Upper \\
\hline \multirow[t]{2}{*}{ Gender } & $\begin{array}{l}\text { Equal } \\
\text { variances } \\
\text { assumed }\end{array}$ & 1.235 & .268 & 1.133 & 204 & .258 & 3.794 & 3.35 & -2.81 & 10.39 \\
\hline & $\begin{array}{l}\text { Equal } \\
\text { variances not } \\
\text { assumed }\end{array}$ & & & 1.015 & 27.740 & .319 & 3.794 & 3.74 & -3.86 & 11.45 \\
\hline \multirow[t]{2}{*}{ Year } & $\begin{array}{l}\text { Equal } \\
\text { variances } \\
\text { assumed }\end{array}$ & 1.918 & .168 & 4.117 & 204 & .000 & 8.639 & 2.09 & 4.51 & 12.77 \\
\hline & $\begin{array}{l}\text { Equal } \\
\text { variances not } \\
\text { assumed }\end{array}$ & & & 4.047 & 171.415 & .000 & 8.639 & 2.14 & 4.43 & 12.85 \\
\hline
\end{tabular}

The results showed analysis of t-test for gender and year of entry obtained significance $>0.05$ meaning that there was no difference in career adaptability between male cadets and female cadets. Likewise, there is also no difference in career adaptability between the first-year cadets and the second-year cadets. 


\section{Discussion}

The aim of this preeliminary study was examine career adaptability of marine cadet and comparing career adaptability in male and female cadets, first-year cadets and second-year cadets. Based on the research findings, the career adaptability level in cadets of Diploma Program in merchant marine education, was relatively high. It shows that the cadets had the capacity to plan and adapt themselves to various changes during their education, in their pursuit of future career. The result also indicates that some cadets were still under the "moderate" and "low" category. Individuals who have high career adaptability are those who adapt easily during transitional period and when facing problems. Some characteristics of individuals with high career adaptability are as follows: (a) capable to focus on future career; (b) having a good sense of self-control in preparing their future career; (c) having curiosity to explore future career opportunities; and (d) self-confident in overcoming obstacles while trying to realize their future career. In contrast, individuals with low level of career adaptability during education process are characterized by: (a) incapability to focus on future career; (b) poor sense of self-control in preparing career pathway; (c) lack of curiosity and exploration of career opportunities; (d) lack of self-confidence during moment of turbulence in the pursuit of future career (Savickas \& Porfeli, 20I2).

The second results of the study showed that there was no difference in career adaptability in male and female cadets, the first-year cadets and the second-year cadets. This results confirms Tian and Fan's study (2014) among baccalaureate student nurses and associate degree student nurses in China which showed no difference in career adaptability between male nurses and female nurses. The results of Ismail et al. (2016) among students in Further Education and Training (FET) South Africa also showed no correlation between gender and career adaptability. In this study the research subjects were cadets who participated in education and training on merchant marine. During the education process, both male and female cadets receive the same education and training and educational rules so that this makes no difference in career adaptability in male and female cadets.

In term of the nature of education, the Diploma Program in merchant marine is a vocational program. So, students were taught skills necessary for jobs after graduation. Vocational programs prepare students to be professionals with standardized working skills (Ristekdikti, 2016). Merchant 
marine vocational program is a higher education program which equips its students with some applied skills, equivalent to those in undergraduate program, to prepare them for jobs in ship navigation sector (Peraturan Menteri Perhubungan No 20 Tahun 2010). In its curriculum, it also includes an internship course which resembles real work conditions, hence cadets will have an actual visualization of the working world and good career planning.

Despite acquiring knowledge and skills about merchant marine science, some cadets still had low and moderate level of career adaptability. Some findings of previous studies shows that career adaptability is affected by personal and environmental factors (Sulistiani \& Handoyo, 20I8). Environmental support, particularly from academic environment, hold significant role in developing one's career adaptability. This notion is supported by some findings which correlated career adaptability and social support. Various sources of support, from parents, social environment, school, to peers, have been investigated in its relation to career adaptability. Findings show that high level of social support is a strong predictor of career adaptability (Hirschi, 2009; Tian \& Fan, 20I4; (Han \& Rojewski, 2015). School support and clinical learning environment support were found positively correlated with subscales of career adaptability on nurses (Tian \& Fan, 20I4; Han \& Rojewski, 2015).

Other findings also indicate that personality is a strong predictor of career adaptability. A study on students in Australia found that goal-oriented learning and optimism were associated with all four dimensions of career adaptability (Tolentino et al., 20l4). Adversity quotient was also found positively associated with career adaptability on nurses (Tian \& Fan, 20I4). Lastly, self-regulation was also reported to have significant correlation with it (Indianti, 20I5; Merino-Tejedor et al., 2016). A research on student of vocational education in Nigeria found a notable correlation between career efficacy, person goal orientation, career future concern, and perceived social support (Shaibu et al., 2016).

\section{Limitation}

This study has its own limitation. Participants of this research were recruited by faculty on account of tight schedule of the students. Not all cadets can fill out the questionnaire in this study. This causes researchers only get data from the first and second year cadets, whereas for career 
adaptability the final cadet cannot be reported. Therefore for generalization of this study should be taken a careful consideration.

\section{Conclusion}

This research conducted a descriptive analysis. Result shows that career adaptability of the marine cadets was fairly high, although some cadets were classified as having moderate and low level of it. The finding also show that all indicators of career adaptability had balanced portions in determining career adaptability. Cadets with low and moderate level of career adaptability should be given extra attention by the university, so they can improve their career adaptability onto a higher level. In addition, the results of this study also showed no difference in career adaptability between male and female cadets, first-year cadets and second-year cadets.

\section{References}

Buyukgoze-kavas, A. (20I4). Validation of the Career Adapt-Abilities Scale-Turkish form and its relation to hope and optimism. Australian Journal of Career Development, 23(3), 125-132. https://doi.org/I0.1 I77//0384I62/453/931

Guan, Y., Wang, F., Liu, H., Ji, Y., Jia, X., Fang, Z., ... Li, C. (2015). Career-specific parental behaviors, career exploration and career adaptability: A three-wave investigation among Chinese undergraduates. Journal of Vocational Behavior, 86, 95-103. https://doi.org//0.1016/j.jvb.2014.10.007

Han, H., \& Rojewski, J. W. (20I5). Gender-specific models of work-bound korean adolescents' social supports and career adaptability on subsequent job satisfaction, Journal of Career Decelopment, 42(2), I49-164. https://doi.org/I0.I I77/08948453/4545786.

Hirschi, A. (2009). Career adaptability development in adolescence: Multiple predictors and effect on sense of power and life satisfaction. Journal of Vocational Behavior, 74(2), I45-I55. https://doi.org/10.1016/j.jvb.2009.01.002

Indianti, W. (20I5). Dukungan sosial dan regulasi diri dalam belajar untuk membangun adaptabilitas karir pada mahasiswa baru universitas Indonesia. Disertasi Universitas Indonesia. Retrieved from http://lib.ui.ac.id/file?file=digital/20 16-4/20416090-D2087-Wahyu Indianti.pdf

Merino-Tejedor, E., Hontangas, P. M., \& Boada-grau, J. (2016). Career adaptability and its relation to self-regulation, career construction, and academic engagement among Spanish university students. Journal of Vocational Behavior, 93, 92-102. https://doi.org/10.1016/j.jvb.2016.01.005 
Peraturan Menteri Perhubungan No 20 Tahun 2010 (2010). Indonesia. Retrieved from http://storage.jak-stik.ac.id/ProdukHukum/Perhubungan/km._no._20_tahun_2010.pdf

Porfeli, E. J., \& Savickas, M. L. (2012). Career adapt-abilities scale-USA Form: Psychometric properties and relation to vocational identity. Journal of Vocational Behavior, 80(3), 748-753. https://doi.org//0.1016/j.jvb.2012.01.009

Ristekdikti. (2016). Buku panduan teknologi pembelajaran pendidikan tinggi vokasi. Jakarta: Ristekdikti.

Rosulin, R., \& Paramita, P. P. (2016). Hubungan antara hardiness dengan adaptabilitas karir pada siswa SMK Kelas XII. Jurnal Psikologi Pendidikan Dan Perkembangan, 5(I), I-II.

Savickas; in Brown, D. (2002). Career choice and development (Fourth Ed). San Fransisco, CA: JosseyBass.

Savickas, M. L. (2007). Career adaptability: An integrative construct for life-span, life-space theory. The Career Development Quarterly, 45, 247-259.

Savickas, M. L., \& Porfeli, E. I. (20I2). Career Adapt-Abilities Scale: Construction, reliability, and measurement equivalence across 13 countries. Journal of Vocational Behavior, 80(3), 66I673. https://doi.org/10.1016/j.jvb.2012.01.011

Shaibu, A., Mat, A., Rahim, A., Shaibu Ebenehi, A., Mat Rashid, A., \& Rahim Bakar, A. (2016). Predictors of career adaptability skill among higher education students in Nigeria. International Journal for Research in Vocational Education and Training (IJRVET), 3(3), 2/2-229. https://doi.org/I0.13 I52/IJRVET.3.3.3

Sufren, \& Natanael, Y. (20I4). Belajar otodidak SPSS Pasti Bisa. Jakarta: PT Elex Media Komputindo.

Sulistiani, W., \& Handoyo, S. (2018). Career adaptability: The influence of readiness and adaptation success in the education context a literature review. In Proceedings of the 3rd ASEAN Conference on Psychology, Counselling, and Humanities (ACPCH 2017) (Vol. I33, PP. 195-205). Atlantis Press. https://doi.org/http://dx.doi.org/I0.299//acpch-17.20I8.32

Sulistiani, W., Suminar, D. R., \& Hendriani, W. (20I8). The career adapt-abilities scale- Indonesian form: Psychometric (Vol. 4, PP. I-9). TIIKM Publishing. https://doi.org// 0.1750I/24246700.2018.4201

Tian, Y., \& Fan, X. (2014). Adversity quotients, environmental variables and career adaptability in student nurses. Journal of Vocational Behavior, 85(3), 25I-257. https://doi.org//0.1016/j.jvb.2014.07.006

Tolentino, L. R., Raymund, P., Garcia, J. M., Nhat, V., Lloyd, S., Restubog, D., ... Plewa, C. (20|4). Career adaptation: The relation of adaptability to goal orientation, proactive personality, and career optimism. Journal of Vocational Behavior, 84(I), 39-48. https://doi.org/10.1016/j.jvb.2013.11.004

Widhiarso, W. (2010). Membuat kategori skor hasil pengukuran dari skala. Universitas Gajah Mada.

Winarno. (2016). Rekonstruksi norma tata tertib taruna sebagai upaya memutus mata rantai $\begin{array}{lllll}\text { kekerasan, } & 3(2), & \text { 274-279. } & \text { Retrieved }\end{array}$ 
Journal of Educational, Health and Community Psychology Vol 8, No 3, 2019 E-ISSN 2460-8467
Sulistiani, Hendriani, Suminar.

jurnal.unissula.ac.id/index.php/PH/article/download/I452/I I 23 